\title{
Erratum zu: 21. Internationales Stuttgarter Symposium
}

Michael Bargende, Hans-Christian Reuss, und Andreas Wagner

\section{Erratum zu:}

M. Bargende et al. (Hrsg.): 21. Internationales Stuttgarter Symposium, Proceedings, S. 1-1, 2021. https://doi.org/10.1007/978-3-658-33521-2

\section{German}

Aufgrund eines Versehens des Verlags wurde das Buch zunächst nur in der Version des ebook. Dabei wurden einige Aktualisierungen in den Kapiteln 2 und 12 übersehen. Die vorliegende PDF-Version unterscheidet sich nur in den Kapiteln 2 und 12 $\mathrm{ab}$ und die fehlenden Inhalte werden nun ergänzt.

\section{English}

Due to an oversight by the publisher, the book was initially published correctly only in the version of the ebook. Some updates were missed in the chapters 2 and 12. The present PDF version differsonly in the chapter 2 and 12 and missed contents are added now.

Die korrigierten Versionen der Kapitel sind verfügbar unter https://doi.org/10.1007/978-3-658-33521-2_2 